\title{
Adoption of Integrated Pest Management for Controlling Pink Bollworm by Bt Cotton Growers
}

\author{
J. M. Deshmukh ${ }^{1 *}$, B. Y. Ghuge ${ }^{1}$ and K. S. Thorat ${ }^{2}$ \\ ${ }^{1}$ Department of Extension Education College of Agriculture, Latur, India \\ ${ }^{2}$ Vasantrao Naik Marathwada KrishiVidyapeeth, Parbhani (M.S.) India \\ *Corresponding author
}

\section{A B S T R A C T}

\section{Keywords}

Integrated pest management, Adoption, Pink bollworm, Profile of Bt cotton growers

Article Info

Accepted:

17 January 2021 Available Online: 10 February 2021
The present study was conducted in Beed district of Marathwada region from Maharashtra state. In Beed district there are 11 tehsils, out of which three tehsils namely Beed, Wadwani and Majalgaon were randomly selected on the basis of area under Bt cotton. From each tehsils 4 villages were randomly selected and from each village 10 respondents were randomly selected to comprise 120 respondents. The result clearly shows that, more than one third $(76.66 \%)$ of farmers had medium level of choice of adoption of cultural practices like summer ploughing, crop rotation, trimming of field bunds, use of resistant varieties, adopting sanitation methods, intercropping and use of trap crops. In case of mechanical control method, it is observed that there are 60.82 per cent of the respondents had medium adoption of mechanical control methods. In case of biological practices of IPM technology, 58.33 per cent of the respondent had medium adoption of pheromone traps, use of trichocards etc. The data presented clearly shows that; majority $(66.67 \%)$ of the farmers had medium level of choice of adoption of chemical control measures like use of various pesticides. Regarding adoption of Integrated Pest Management to control the pink bollworm of Bt cotton shows that, 66.67 per cent of farmers had medium adoption.

\section{Introduction}

Pink bollworm (Pectinophora gossypiella Saund.) has now emerged as a major pest of cotton in all cotton growing areas in India. The pest mainly fed on seeds causing economic loss. Infestation occurs in mid and late stages of the crop; it remains undetected due to feeding behaviour and causes loss of yield quality. It impacts boll opening, coinciding with the second picking of cotton in most areas. The colour pink is associated with love, beauty and fashion. But in Vidarbha region of Maharashtra, Pink Bollworm has become synonymous with death and destruction. Pink Bollworm has ravaged the cotton crop in the district, where farmer suicide has been rampant. The Pink Bollworm eats away the cotton fiber and the bolls, causing economic loss to the farmer. According to the year witnessed Pink Bollworm (PBW) attacks on cotton, especially in Maharashtra and also in Telangana, Andhra Pradesh and Karnataka. 
The infestation of this insect pest, whose larvae bore into cotton bolls through the lint fibre to feed on the seeds happened during October, just when the crop was maturing and almost this time was that farmers there had planted a record 42 lakh plus hectares under cotton, encouraged by the previous year's remunerative realizations.

Integrated Pest Management (IPM) has been defined as a sustainable approach to managing pests by combining biological, cultural, physical and chemical tools in a way that minimizes economic, health and environmental risks (Greenberg et al., 2012). IPM involves a number of pest management practices that are both location and crop specific. It has also been defined as a knowledge-based decision-making process that anticipates limits and eliminates or prevents pest problems, ideally before they have become established (Greenberg et. al., 2012). Integrated Pest Management (IPM) in cotton involves using all available techniques for managing pest populations with the aim of reducing pesticide use while maintaining profitability, yield and fibre quality.

Maharashtra state particular has faced the problem of control of pink bollworm in cotton as a more pronounced during last year and the incidence has been identified from the middle of crop season seriously damaging the cotton in late pickings. The pink bollworm control on cotton has become a tough task because the larval stages of this pest were spent within the cotton bolls.

Therefore, conventional control methods including insecticidal applications felt difficult to control the pest. Hence the present study with objective to know the adoption of Integrated Pest Management technologies for controlling pink bollworm by Bt. cotton growers.
The main objective of this study to know the adoption of Integrated Pest Management technologies for controlling pink bollworm by Bt cotton growers.

\section{Materials and Methods}

The present study was conducted in Beed district of Marathwada region from Maharashtra state. In Beed district there are 11 tehsils, out of which three tehsils namely Beed, Wadwani and Majalgaon were purposively selected on the basis of area under Bt cotton. From each tehsil 4 villages were purposively selected on the basis of area under $\mathrm{Bt}$ cotton and from each village 10 respondents were randomly selected to comprise 120 respondents. Ex-post facto research design was used for the study.

Data was collected by personally interviewing the respondents with the help of pretested structural schedule. Collected data was tabulated properly. Mean and standard deviation, frequency, percentage were used for interpretation of data.

\section{Results and Discussion}

\section{Profile of farmers}

\section{Adoption of integrated pest management technologies for controlling pink bollworm by $B t$ cotton growers}

\section{Cultural control measures}

Cultural pest control is the management of pests by manipulation of the environment or implementation of preventive practices including using plants that are resistant to pest, raising the mowing height of turf to shade out weeds, aerating turf to reduce compaction and plant stress, dethatching to remove habitat, food sources and impediments to management, etc. 
The data presented in Table 1 clearly shows that, more than one third $(76.66 \%)$ of farmers had medium level of choice of adoption of cultural practices like summer ploughing, crop rotation, trimming of field bunds, use of resistant varieties, adopting sanitation methods, intercropping and use of trap crops etc. While 15.00 per cent of farmers adopt cultural practices at high level whereas; only 8.83 per cent farmers prefers to adopt the cultural practices at low level.

\section{Mechanical control measures}

Mechanical Control is management and control of pest using physical means such as fences, barriers, or electronic wires. It includes also weeding and change of temperature to control pests. farmers are trying to find sustainable ways to remove pest without harming the ecosystem.

In case of mechanical control method, it is observed that from Table 1, there are 60.82 per cent of the respondents had medium adoption of mechanical control methods while, 20.00 per cent and 19.16 per cent of the respondents had low and high adoption of mechanical control measures respectively

\section{Biological control measures}

Biological Control Measures includes using one organism to control another, as in attracting or releasing beneficial insects that are natural enemies of pest species into the landscape and protecting the beneficial that exists in the landscape.

Table.1 Distribution of respondents according to their adoption of IPM technologies controlling pink bollworm by Bt cotton growers

\begin{tabular}{|c|c|c|c|c|}
\hline Sl. No. & \multirow{2}{*}{\multicolumn{2}{|c|}{$\begin{array}{l}\text { Integrated Pest Management Technologies } \\
\text { Cultural control Methods }\end{array}$}} & \multicolumn{2}{|c|}{ Respondents (N=120) } \\
\hline \multirow[t]{5}{*}{1} & & & Frequency & Percentage \\
\hline & & Low (up to 10) & 10 & 8.83 \\
\hline & 2. & Medium (11 to 13 ) & 92 & 76.66 \\
\hline & 3. & High (above 13) & 18 & 15.00 \\
\hline & & Total & 120 & 100.00 \\
\hline \multirow[t]{5}{*}{2} & \multicolumn{2}{|c|}{ Mechanical control Methods } & & \\
\hline & 1. & Low (up to 4) & 24 & 20.00 \\
\hline & 2. & Medium (5 to 7 ) & 73 & 60.82 \\
\hline & 3. & High (above 7) & 23 & 19.16 \\
\hline & & Total & 120 & 100.00 \\
\hline \multirow[t]{5}{*}{3} & \multicolumn{2}{|c|}{ Biological control Methods } & & \\
\hline & 1. & Low (up to 4) & 28 & 23.33 \\
\hline & 2. & Medium (5 to 6) & 70 & 58.33 \\
\hline & 3. & High (above 6) & 22 & 18.33 \\
\hline & & Total & 120 & 100.00 \\
\hline \multirow[t]{4}{*}{4} & \multicolumn{4}{|c|}{ Chemical control Methods } \\
\hline & 1. & Low (up to 1) & 26 & 21.66 \\
\hline & 2. & Medium (2 to 3 ) & 80 & 66.67 \\
\hline & 3. & High (above 3 ) & 14 & 11.66 \\
\hline
\end{tabular}


Table.2 Overall Adoption of IPM practices for controlling pink bollworm by Bt cotton growers

$$
\mathrm{N}=120
$$

\begin{tabular}{|l|l|c|c|}
\hline Sr.No & Adoption & Frequency & Percentage \\
\hline 1. & Low (up to 22) & 24 & 20.00 \\
\hline 2. & Medium (23 to 29) & 80 & 66.67 \\
\hline 3. & High (above 29) & 16 & 13.33 \\
\hline & Total & $\mathbf{1 2 0}$ & $\mathbf{1 0 0 . 0 0}$ \\
\hline
\end{tabular}

In case of biological practices of IPM technology, 58.33 per cent of the respondent had medium adoption of pheromone traps, use of trichocards etc. 23.33 per cent and 18.34 per cent of the respondents had low and high adoption of biological practices of IPM technology used in cotton for controlling of pink bollworm respectively.

\section{Chemical control measures}

Chemical control measures may refers to any method to eradicate or limit the growth of pathogens which transmit disease to plants or animals especially insecticides.

The data presented in Table 1 clearly shows that, majority $(66.67 \%)$ of farmers had medium level of choice of adoption of chemical control measures like use of various pesticides, use of pyrethroides etc. While 11.66 per cent of the farmers adopt cultural practices at high level whereas; only 21.66 per cent of farmers prefer to adopt the chemical control measures at low level.

Data from the Table 2 portray the results regarding adoption of Integrated Pest Management to control the pink bollworm of $\mathrm{Bt}$ cotton that, 66.67 per cent of farmers had medium adoption, 13.33 per cent farmers had high adoption of IPM practices followed by low (20.00\%) adoption level of IPM practices in $\mathrm{Bt}$ cotton to control pink bollworm. The findings of present study were similar to findings of Yadav et al., (2017), Himdari et al., (2018).

In conclusion, the result clearly shows that, most of the farmers found in medium category of adoption of cultural, mechanical, mechanical and chemical practices of Integrated Pest Management technology. Results regarding overall adoption of Integrated Pest Management to control the pink bollworm of Bt cotton shows that, 66.67 per cent of farmers had medium adoption level of IPM for controlling pink bollworm by the cotton growers.

\section{References}

Greenberg S.M., J.J. Adamcyzk and J.S. Armstrong (2012) Principles and practices of Integrated Pest Management on cotton in the Lower Rio Grande Valley of Texas. www.intechopen.com

Himdari, R., D. M. Mankar, Rohit Shelar, Ravi K.N. Awadhesh, K.S. (2018). Assessing the extent of adoption of improved $\mathrm{Bt}$ cotton cultivation practices by the $\mathrm{Bt}$ cotton Thesis (Unpublished), GAU, Sardar Krushinagar.

Yadav, S., Gadara, A.K. and Yadav, V.P. (2017). Adoption of Bt Cotton Production Technology by the Growers in Haryana. Indian Res. J. Ext. Edu. 17(4): 8-11.

\section{How to cite this article:}

Deshmukh, J. M., B. Y. Ghuge and Thorat, K. S. 2021. Adoption of Integrated Pest Management for Controlling Pink Bollworm by Bt Cotton Growers. Int.J.Curr.Microbiol.App.Sci. 10(02): 19041907. doi: https://doi.org/10.20546/ijcmas.2021.1002.226 